\title{
Decomposition of dissolved organic matter from the continental margin
}

\author{
Charles S. Hopkinson Jr.*, Joseph J. Vallino, Amy Nolin \\ Ecosystems Center, Marine Biological laboratory, Wood Hole Oceanographic Institute, Woods Hole, MA 02543, USA
}

Accepted 14 February 2002

\begin{abstract}
Decomposition of dissolved organic carbon, nitrogen and phosphorus (DOC, DON, DOP) was measured for surface and bottom waters of the middle Atlantic bight (MAB) and deep slope water adjacent to the MAB on two occasions in March and August 1996. We used standard bottle incubation techniques to measure the decrease in dissolved organic matter (DOM) concentrations over a 180-day interval. Generally DOM concentrations in the MAB were elevated $(125 \mu \mathrm{M}$ DOC, $10.2 \mu \mathrm{M}$ DON and $0.30 \mu \mathrm{M}$ DOP) relative to the surface ocean and deep slope water $(46.7 \mu \mathrm{M}$ DOC, $2.76 \mu \mathrm{M}$ DON, $0.03 \mu \mathrm{M}$ DOP). On average the C:N:P ratio of shelf DOM (431:36:1) was substantially higher than the Redfield ratio, but not nearly as high for that of deep slope water (2700:215:1). Decomposition time course data were fit to a three-pool (very labile, labile, and recalcitrant pools) multi-G model using a Marquardt fitting routine. The threepool model was superior to a simple exponential decay model assuming a single pool of DOM. We observed no significant changes in concentration of DOM in deep-water samples, attesting to the old age of this material, its recalcitrant nature, and the cleanliness of our technique for measuring decomposition. There were major differences in the relative amount of very labile, labile and recalcitrant fractions of shelf-water DOC, DON and DOP as a result of preferential remineralization of $\mathrm{P}$ over $\mathrm{N}$ and $\mathrm{N}$ over $\mathrm{C}$. Averaged over stations, the decomposable portion of the bulk DOC, DON and DOP pools increased from $30 \%$ to $40 \%$ to $81 \%$ for $\mathrm{C}, \mathrm{N}$ and $\mathrm{P}$. There was a wide range in decay coefficients for the very labile and labile DOM pools: average decay coefficient for the very labile pool was $0.219 \mathrm{~d}^{-1}$, and $0.018 \mathrm{~d}^{-1}$ for the labile pool. Average half-lives calculated from the decay coefficients were 4,12 and 8 days for the very labile DOC, DON and DOP pools, and 54, 113 and 90 days for the labile DOC, DON and DOP pools. On the basis of pool turnover times relative to shelf-water residence time ( $\sim 100$ days) we conclude that autochthonous algal production is the source of the very labile DOM pools. Its rate of production is sufficient to sustain estimated rates of bacteria $\mathrm{C}$ demand in continental margins. Our results for the MAB indicate that while substantial amounts of DOM are remineralized in the same time frame as shelf-water residence time, there is substantial DOM remaining that is depleted in N and P relative to C. Strong concentration gradients in DOM occur between shelf and ocean waters and between surface and deeper waters. Coupled with appropriate vertical and horizontal advective and eddy diffusive transports, DOM export from the MAB and other shelf systems may be a significant component of ocean C dynamics. (C) 2002 Elsevier Science Ltd. All rights reserved.
\end{abstract}

\footnotetext{
*Corresponding author. Tel.: + 1-508-298-7688; fax: + 1-508-457-1548.

E-mail address: chopkins@mbl.edu (C.S. Hopkinson Jr.).
} 


\section{Introduction}

There is great interest in dissolved organic carbon (DOC) in the ocean, primarily out of concern for a better understanding of the global carbon cycle and the fact that DOC is overwhelmingly the largest pool of organic carbon in the ocean. On a global scale, the pool of DOC is of the same magnitude as atmospheric $\mathrm{CO}_{2}$, and it accounts for about $20 \%$ of the organic material on the globe (excluding kerogen and coal; Hedges, 1992). Continental shelves may play a disproportionately large role in oceanic carbon cycling because shelves are conduits linking terrestrial sources of organic matter with the ocean and they are the sites where approximately $20 \%$ of oceanic primary production occurs (Schlesinger, 1997). An appreciation of the role of limiting factors in controlling primary productivity dictates the need for equivalent understanding of the dynamics of dissolved organic nitrogen and phosphorus (DON and DOP). The extent to which organic $\mathrm{N}$ and $\mathrm{P}$ are coupled or decoupled from organic $\mathrm{C}$ decomposition is critical to understanding controls of the biological pump, or the transfer of organic carbon produced in the surface ocean to depths in the ocean. Decoupling N and P remineralization from $\mathrm{C}$ remineralization would enable remineralized $\mathrm{N}$ and $\mathrm{P}$, which are often at limiting levels in the surface ocean, to continue to support organic matter production and thereby drive a larger export flux of $\mathrm{C}$ than could otherwise be supported.

DOC, DON and DOP accumulate in surface waters of the ocean, due to a variety of processes beginning with primary production (Carlson et al., 1994). In the North Atlantic, accumulation and vertical carbon export of DOC are thought to assume an important role in oceanic carbon balance that is in addition to the classical model of particle export (Carlson et al., 1994; Ducklow et al., 1995). While considerable information exists to describe the $\mathrm{C}: \mathrm{N}: \mathrm{P}$ stoichiometry of particle formation, settling and remineralization (Martin et al., 1987), relatively little is known about the corresponding processes for dissolved organic matter (Hopkinson et al., 1997).
Our knowledge of DOM turnover is rudimentary for any aquatic system, but especially for continental shelves and the ocean. Although the average elemental composition of DOM can be measured, very little is known about the distributions of $\mathrm{C}, \mathrm{H}, \mathrm{N}$, and $\mathrm{O}$ in specific, identifiable organic compounds. Münster (1993) estimated that $10-20 \%$ of DOM could often be identified as specific compounds. The remaining $80-90 \%$ of DOM is a highly complex mixture that cannot be resolved into pure compounds. Recent reports of temporal variability in surface water DOC concentrations (Carlson et al., 1994) suggest that only a portion of the bulk DOC pool is labile. Direct measures of oceanic DOC consumption by microbes suggest that very little $(<10 \%)$ of the bulk pool is labile (Carlson and Ducklow, 1996). Experimental studies with isotopically labeled DOC (Norrman et al., 1995; Fry et al., 1996) and radiocarbon studies of DOC (Raymond and Bauer, 2001) have demonstrated a wide range in lability of bulk DOC, with turnover times ranging from hours to years and ages ranging from modern to over a thousand years (Williams and Druffel, 1987; Bauer and Druffel, 1998). In general, residence times of shelf waters are short relative to the age of much of the DOC pool. Therefore, if advective and eddy diffusive transports are of sufficient magnitude, fluxes of DOC could be greater than sinking POC fluxes (Ledwell et al., 1993; Bauer et al., 2000). While there are a few reports of oceanic DOC decomposition, there is only one study we are aware of reporting oceanic DON and DOP remineralization (Hopkinson et al., 1997). Estimates of DON and DOP remineralization are typically inferences made from information on DOM depth profiles and water turnover times and ages (e.g., Jackson and Williams, 1985).

DOM is composed of a suite of organic compound classes with turnover times ranging from seconds, hours, days, years to millennia (see for example, Williams and Druffel, 1987; Coffin et al., 1993; Cherrier et al., 1996; Fry et al., 1996). Knowledge of the sizes and turnover times of discrete DOM pools is essential to accurate accounting and modeling of global ocean $\mathrm{C}$ dynamics. Because of the differential $\mathrm{C}, \mathrm{N}$ and $\mathrm{P}$ 
content of various organic compound classes composing cellular structures and contents, we might expect there to be inherent differences in decomposition rates of organic $\mathrm{C}, \mathrm{N}$ and $\mathrm{P}$ compounds and the relative proportions of discrete pools of organic matter. As the relative proportions of $\mathrm{C}, \mathrm{N}$ and $\mathrm{P}$ in biomolecules also vary, we might further expect the turnover times of organic $\mathrm{C}, \mathrm{N}$ and $\mathrm{P}$ to differ. A number of studies have demonstrated preferential remineralization of $\mathrm{N}$ and $\mathrm{P}$ relative to $\mathrm{C}$ (Martin et al., 1987; Williams et al., 1980; Hopkinson et al., 1997). There is very limited information for aquatic systems, however, on the relative pool sizes of C, $\mathrm{N}$ and $\mathrm{P}$ containing organic matter of differing lability. The information is limited primarily to lability of organic carbon.

Here we present the results of a study characterizing pool sizes and decomposition rates of dissolved organic $\mathrm{C}, \mathrm{N}$ and $\mathrm{P}$ on the continental shelf of the middle Atlantic bight (MAB). Bulk DOM is characterized on the basis of the decrease in decomposition rate over time as being very labile, labile or recalcitrant. Estimates of the halflives of these fractions as well as turnover times of the bulk organic $\mathrm{C}, \mathrm{N}$ and $\mathrm{P}$ pools are determined. These time scales are of relevance to understanding microbial dynamics and the role of continental shelf systems in the context of the larger oceanic C cycle.

\section{Materials and methods}

\subsection{Study area}

The middle Atlantic bight (MAB) consists of the continental shelf region extending from south of Georges Bank to Cape Hatteras along the eastern US coast (Fig. 1). The MAB is under the influence of the Gulf Stream, the Labrador Current as well as several other sources (Pietrafesa et al., 1994). There is a net southwesterly flow of water along the coast driven partially by buoyancy forces stemming from freshwaters entering from rivers. A permanent shelf water/slope water thermohaline front confines the surface waters of the area (Biscaye et al., 1994). There is significant exchange of water along the shelf/slope front, resulting in an average water residence time in the MAB of 100

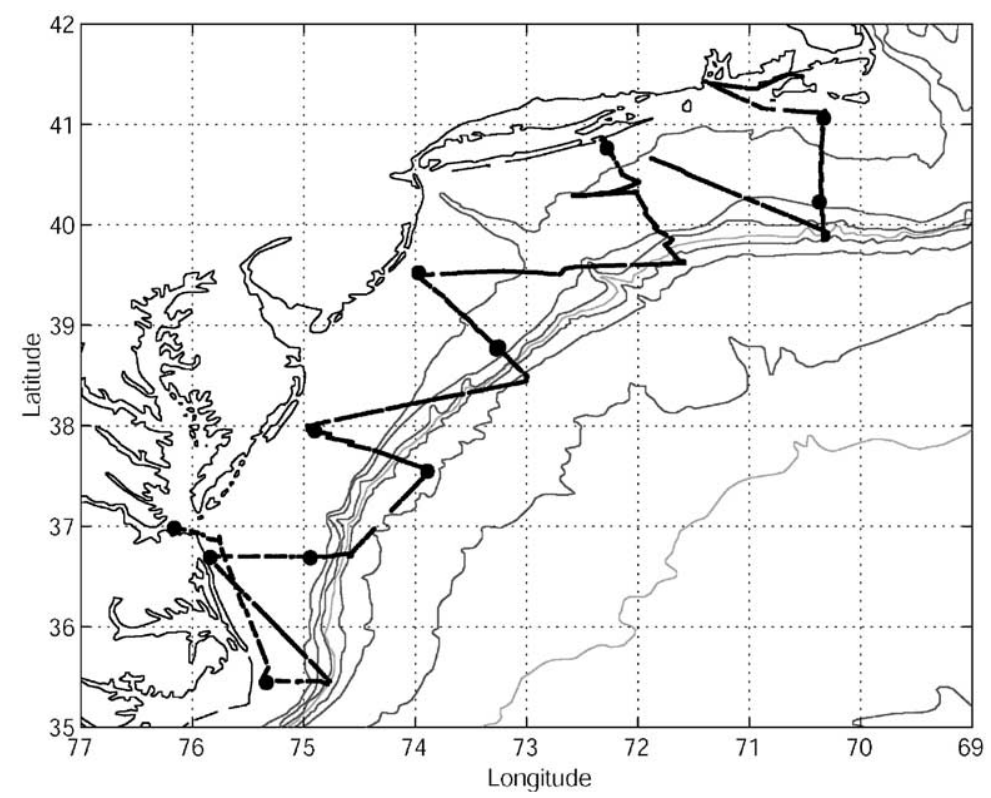

Fig. 1. Map of the middle Atlantic bight showing approximate locations ( $)$ where samples were collected in March and August 1996. 
days, which is shorter than the average transport time for a parcel traveling the full length of the MAB.

\subsection{Methods}

DOM decomposition was examined by incubating filtered water in 50-ml flame-sealed glass ampoules. Samples were stored at room temperature $\left(19-20^{\circ} \mathrm{C}\right)$ in total darkness. Replicate samples (three) were sacrificed following approximately $0,3,12,31,90$ and 180 days. Changes in concentration of DOC, DON and DOP over time were used to estimate DOM decomposition rate. As inorganic nutrients, $\mathrm{NH}_{4}^{+}, \mathrm{NO}_{3}^{-}$and $\mathrm{PO}_{4}^{3-}$ were also measured, DOM time series compromised because of sampling or processing errors could be corrected. We found mirror images between DOM decrease and inorganic nutrient increase (data not shown). The time-series approach using replicated incubation bottles has been used previously to assess DOC dynamics as well as bacterial growth dynamics (e.g., Coffin et al., 1993).

One to three stations on each of six transects across the MAB shelf and slope between southern Martha's Vineyard and Cape Hatteras were sampled in March and August 1996. Samples were from a variety of inner and outer shelf locations (Fig. 1 and Table 1). We collected mostly surface water, but during each sampling trip bottom water was collected from the outer shelf as well as off the shelf break in water up to $1660 \mathrm{~m}$ deep. In March a surface water sample was also obtained from the lower Chesapeake Bay. Samples were collected with 20- or 30-1 Niskin bottles mounted on 12bottle rosettes on the R.V. Endeavor (EN279) in March 1996 and the R.V. Seward Johnson (SJ9608) in August 1996. Samples were gravity drained through a teflon tube with a $208-\mu \mathrm{m}$ Nitex screen into a clean, polycarbonate (acid-washed and DI rinsed) 10-1 carboy with spigot. Thus, an intact microbial and microplanktonic community was maintained. We assume that predator-prey interactions between the various microbial communities maintained an overall constancy of biomass. Water was rapidly brought to room temperature (10-15 $\mathrm{min})$ and the gas phase equili- brated with the atmosphere. The water was heated with an infrared heat lamp (IR radiation spectrum verified) and equilibrated by stirring with a tefloncoated stir bar and bubbling with filtered shipboard room air. The air stream was cleansed by passing through $\mathrm{CuO}$ and silica gel beads. Water was then gravity fed from the carboy spigot through teflon and glass tubing into incubation vessels. For measuring DOC, DON, DOP and inorganic nutrients, water was drained into $50-\mathrm{ml}$, precombusted, glass ampoules. Ampoules were rinsed 3 times with sample and then heat-sealed. Replicate ampoules were immediately sampled for initial values. Ampoules were sampled by rapid freezing and then held frozen for up to 6 months for nutrient analysis. We used glass ampoules that can be flame-sealed because we have observed significant contamination across screw cap and sintered glass bottles. Dissolved oxygen was initially in equilibrium with the atmosphere $\left(>250 \mu \mathrm{M} \mathrm{O}_{2}\right)$ and therefore in excess of that required to oxidize all dissolved organic matter.

The cleanliness of our incubation set-up procedure was evidenced by agreement between our initial DOC concentrations and those determined from on-board measurements from the same Niskin bottles (R. Chen, pers. comm.). It was also determined by incubating deep water, which has very low concentrations of primarily recalcitrant dissolved organic matter. We expect this water to be biologically "inert" in the sense that concentrations are not expected to vary over 180-day incubations unless there is contamination with new or labile organic matter.

Nutrient samples were stored frozen until the end of the 180-day incubation period. For DOC analysis, upon thawing samples were acidified to pH 2 with $500 \mu \mathrm{l}$ of $50 \%$ phosphoric acid and bubbled with ultra-pure $\mathrm{O}_{2}$ to remove inorganic $\mathrm{C}$. DOC was analyzed following high temperature oxidation. The DOC instrument (designed by Ed Peltzer and manufactured by Woods Hole Oceanographic Institution; Peltzer and Brewer, 1993; Peltzer and Hayward, 1996; Peltzer et al., 1996) employs a two-zoned furnace $\left(800^{\circ} \mathrm{C}\right.$ top $-600^{\circ} \mathrm{C}$ bottom) with $\mathrm{Pt}$ on alumina catalyst, $\mathrm{CuO}$ and Sulfix in the combustion zone, a dehumidification system, dual particle filters, a solid-state NDIR 
Table 1

Station locations and basic water column characteristics during sampling

\begin{tabular}{|c|c|c|c|c|c|c|c|c|}
\hline \multirow{2}{*}{$\begin{array}{l}\text { Date Stn. } \\
\text { Name } \\
\text { March } 1996\end{array}$} & \multirow[t]{2}{*}{$\begin{array}{l}\text { Coordinates } \\
\text { Deg N-W }\end{array}$} & \multirow[t]{2}{*}{ Stn Z (m) } & \multirow[t]{2}{*}{ Spl Z (m) } & \multirow[t]{2}{*}{ Temp $\left({ }^{\circ} \mathrm{C}\right)$} & \multicolumn{3}{|c|}{ Salinity (ppt) $[\mathrm{Chl}]\left(\mu \mathrm{gl}^{-1}\right)\left[\mathrm{NO}_{3}^{-}\right](\mu \mathrm{M})$} & \multirow[t]{2}{*}[\mathrm{PO}_{4}^{3-}]{$(\mu \mathrm{M})$} \\
\hline & & & & & & & & \\
\hline $\mathrm{T} 1 \mathrm{~S} 1$ & $\begin{array}{ll}41 & 07.11 \\
70 & 20.53\end{array}$ & 36 & 5.1 & 2.635 & 32.33 & 4.9 & 0.18 & 0.08 \\
\hline T1S4 & $\begin{array}{ll}40 & 37.03 \\
70 & 20.97\end{array}$ & 60 & 3.8 & 3.602 & 32.704 & 6.6 & 4.36 & 0.37 \\
\hline $\mathrm{T} 2 \mathrm{~S} 1$ & $\begin{array}{ll}40 & 50.88 \\
72 & 19.77\end{array}$ & 27 & 5 & 2.172 & 31.844 & 2.6 & 2.68 & 0.46 \\
\hline T3S1 & $\begin{array}{ll}39 & 30.01 \\
73 & 57.95\end{array}$ & 24 & 2.1 & 2.947 & 32.271 & 8.1 & 0.3 & 0.21 \\
\hline $\mathrm{T} 3 \mathrm{~S} 4$ & $\begin{array}{ll}39 & 04.56 \\
73 & 32.9\end{array}$ & 55 & 16 & 4.085 & 33.015 & 3.3 & 0.11 & 0.25 \\
\hline $\mathrm{T} 4 \mathrm{~S} 1$ & $\begin{array}{l}3759.94 \\
7458.02\end{array}$ & 23 & 3.6 & 4.505 & 32.457 & 2.7 & 0.41 & 0.25 \\
\hline $\mathrm{T} 4 \mathrm{~S} 7$ & $\begin{array}{l}3735.40 \\
7357.06\end{array}$ & 1600 & 750 & 4.486 & 34.996 & 0 & 18.58 & 0.95 \\
\hline T5S1 & $\begin{array}{l}3642.02 \\
7551.99\end{array}$ & 14 & 4.9 & 4.692 & 29.334 & 4.1 & 0.12 & 0.18 \\
\hline T5S4 & $\begin{array}{l}3642.00 \\
755.94\end{array}$ & 34 & 5.7 & 6.926 & 33.537 & 5.1 & 0.54 & 0.12 \\
\hline T6S1 & $\begin{array}{ll}35 & 27.42 \\
75 & 23.09\end{array}$ & 19 & 4.8 & 6.207 & 31.366 & 1.7 & 0.55 & 0.04 \\
\hline ChesBay & $\begin{array}{l}3653.12 \\
7545.43\end{array}$ & 23 & 2 & 4.009 & 31.378 & 4.8 & 0.55 & 0.17 \\
\hline August 199 & & & & & & & & \\
\hline $\mathrm{T} 1 \mathrm{~S} 1$ & $\begin{array}{ll}41 & 06.65 \\
70 & 21.36\end{array}$ & 40 & 3.7 & 14.161 & 31.622 & 2.14 & 0 & 0.16 \\
\hline $\mathrm{T} 1 \mathrm{~S} 4$ & $\begin{array}{ll}40 & 37.02 \\
70 & 20.99\end{array}$ & 59 & 3.3 & 15.156 & 32.022 & 0.8 & 0 & 0.08 \\
\hline $\mathrm{T} 2 \mathrm{~S} 1$ & $\begin{array}{ll}40 & 29.77 \\
72 & 19.99\end{array}$ & 23 & 4.1 & 19.127 & 30.021 & 1.8 & 0.03 & 0.15 \\
\hline T3S1 & $\begin{array}{ll}39 & 29.92 \\
73 & 58.08\end{array}$ & 23 & 3.6 & 21.377 & 30.436 & 1.1 & 0 & 0 \\
\hline T3S4 & $\begin{array}{ll}39 & 04.74 \\
73 & 33.09\end{array}$ & 54 & 3.7 & 21.621 & 30.756 & 0.5 & 0.32 & 0.09 \\
\hline $\mathrm{T} 4 \mathrm{~S} 1$ & $\begin{array}{ll}38 & 00.11 \\
74 & 58.30\end{array}$ & 21 & 3.9 & 22.989 & 29.998 & 0.46 & 0 & 0.05 \\
\hline $\mathrm{T} 4 \mathrm{~S} 7$ & $\begin{array}{l}3734.86 \\
7355.97\end{array}$ & 1660 & 1500 & 3.621 & 34.918 & 0 & 17.9 & 0.88 \\
\hline T5S1 & $\begin{array}{ll}35 & 42.00 \\
75 & 51.98\end{array}$ & 15 & 4.4 & 23.986 & 24.876 & 1.1 & 0.3 & 0.06 \\
\hline T5S4 & $\begin{array}{ll}36 & 42.01 \\
75 & 17.28\end{array}$ & 25 & 24.9 & 11.705 & 32.258 & 4.7 & 0.09 & 0.27 \\
\hline T5S5 & $\begin{array}{l}3642.00 \\
746.05\end{array}$ & 31 & 3.8 & 24.285 & 30.780 & 0.4 & 0.15 & 0.04 \\
\hline T6S1 & $\begin{array}{ll}35 & 26.93 \\
75 & 23.08\end{array}$ & 20 & 4.7 & 23.073 & 30.527 & 0.9 & 0.06 & 0.02 \\
\hline
\end{tabular}

detector, and a PC-based integration system. Analysis precision and accuracy were determined by multiple injections of carbon-free distilled water and deep ocean water of known DOC concentration. Our instrument and analysts have successfully analyzed the "Sharp intercomparison 
samples" for DOC analysis (Jon Sharp, pers. commun.). Our routine precision is better than $5 \%$ or $2-3 \mu \mathrm{M} \mathrm{C}$ at low concentrations.

DON and DOP were analyzed as total dissolved $\mathrm{N}$ and $\mathrm{P}$ (TDN, TDP) minus inorganic $\mathrm{N}$ and $\mathrm{P}$ $\left(\mathrm{DIN}-\mathrm{NH}_{4}^{+}, \mathrm{NO}_{3}^{-}\right.$and $\mathrm{NO}_{2}^{-} ; \mathrm{DIP}-\mathrm{PO}_{4}^{3-}$ ). We followed the UV oxidation procedure of Walsh (1989). We find high recoveries of standards and precision between $4-8 \%$ as long as we use new $\mathrm{H}_{2} \mathrm{O}_{2}$ and UV radiation is high. Standard colorimetric analysis was used to measure $\mathrm{NH}_{4}^{+}$, and $\mathrm{PO}_{4}^{3-}$. A chemiluminscence nitrogen oxide analyzer (NOX box) was used to measure $\mathrm{NO}_{3}^{-}$ following the conversion of $\mathrm{NO}_{2}^{-}$and $\mathrm{NO}_{3}^{-}$to NO gas (after Garside, 1982). Reagent blanks were treated as with standard inorganic nutrient analysis. Analysis precision and accuracy were determined from standard curves prepared from carbon-free distilled water and five concentrations of urea. Chlorophyll $a$ concentrations were measured by personnel at the Brookhaven National Laboratory under the direction of Douglas Wallace from archived frozen samples.

A multi-G model was used to describe the decomposition of the dissolved organic matter (Berner, 1980). This model describes the decomposition of organic matter as the simultaneous loss of discrete pools of organic matter each with characteristic decomposition rates. We used a Marquardt nonlinear least-squares fitting routine (Press et al., 1986) to estimate pool sizes and decay rates for three DOM components: very labile DOM $\left(\mathrm{C}_{1}\right)$, labile DOM $\left(\mathrm{C}_{2}\right)$ and recalcitrant $\operatorname{DOM}\left(\mathrm{C}_{3}\right)$. DOM decomposition was described as the exponential decay of the two labile pools with a background pool of recalcitrant DOM, according to the equation:

$C_{\mathrm{T}}=C_{1} \mathrm{e}^{-k_{1} t}+C_{2} \mathrm{e}^{-k_{2} t}+C_{3}$,

where $C_{\mathrm{T}}$ is the total DOM concentration at time $t, \mathrm{C}_{1}$ is size of the very labile pool, $\mathrm{C}_{2}$ is the labile pool size, $\mathrm{C}_{3}$ is the recalcitrant pool size, and $k_{1}$ and $k_{2}$ are the instantaneous decay rates of the very labile $\left(\mathrm{C}_{1}\right)$ and labile $\left(\mathrm{C}_{2}\right)$ pools. To decrease the degrees of freedom in the least-squares routine, we set $\mathrm{C}_{1}$ as the difference between $C_{\mathrm{T}}$ and $\mathrm{C}_{2}$ plus $\mathrm{C}_{3}$. The fitting routine required initial estimates for each of the parameters and values of dissolved organic matter concentrations for each sampling time. The overall goodness of fit was calculated as the mean squared error.

\section{Results and discussion}

\subsection{Initial conditions}

There were large differences in ambient conditions between March and August in 1996. Water samples collected in March were typically colder, more saline, and had higher chlorophyll and dissolved inorganic $\mathrm{N}$ and $\mathrm{P}$ concentrations than in August (Table 1). Water temperatures ranged from $2.1^{\circ} \mathrm{C}$ to $6.9^{\circ} \mathrm{C}$ and averaged $4.2^{\circ} \mathrm{C}$ in March, and from $3.6^{\circ} \mathrm{C}$ to $24.3^{\circ} \mathrm{C}$ averaging $19.7^{\circ} \mathrm{C}$ in August. Surface waters were often colder than deep slope water in March. Even though river discharge was higher in March and average slope salinity was undoubtedly lower in March than in August, samples collected in August for decomposition analysis were on average less salty. Chlorophyll $a$ concentrations in shelf waters collected for decomposition analysis ranged from $1.7-8.1 \mu \mathrm{g} 1^{-1}$ in March to $0.4-4.7 \mu \mathrm{gl}^{-1}$ in August. Chlorophyll was undetectable in slope deep water. Thus, incubation samples to some degree reflect spring bloom conditions that were underway in March. $\mathrm{NO}_{3}^{-}$and $\mathrm{PO}_{4}^{3-}$ concentrations in incubation water samples from the shelf ranged from undetectable to $4.4 \mu \mathrm{M} \mathrm{N}$ and undetectable to $0.46 \mu \mathrm{M} \mathrm{P}$ in March and from undetectable to $0.32 \mu \mathrm{M} \mathrm{N}$ and undetectable to $0.27 \mu \mathrm{M} \mathrm{P}$ in August. Inorganic N and $\mathrm{P}$ were substantially higher in deep slope water in March and August than in any shelf or estuarine water sample.

DOC, DON, and DOP concentrations were similar in March and August: averaging 115, 10.0, $0.31 \mu \mathrm{M} \mathrm{C}, \mathrm{N}, \mathrm{P}$ and $129,10.3,0.28 \mu \mathrm{M} \mathrm{C}, \mathrm{N}$ and $\mathrm{P}$, respectively. DOM was typically highest in water collected at the inner shelf stations and lower offshore. Excluding slope deep water, which had concentrations typical of oceanic deep water, DOC concentrations ranged from 81 to $143 \mu \mathrm{M} \mathrm{C}$ in March and from 94 to $201 \mu \mathrm{M} \mathrm{C}$ in August. Shelf DON ranged from 7.9-12.6 $\mu \mathrm{M} \mathrm{N}$ in March and from 7.1-14.3 $\mu \mathrm{M} \mathrm{N}$ in August. Shelf DOP 
ranged from $0.25-0.42 \mu \mathrm{M} \mathrm{P}$ in March and from $0.14-0.37 \mu \mathrm{M} \mathrm{P}$ in August. DOM concentrations in the single shelf bottom-water samples from March and August were within the range observed in shelf surface waters. The August bottom-water sample was collected from the "cold pool" water mass, which is a filament of water that originates at the head of the middle Atlantic bight near Georges Bank and runs along the outer $1 / 3$ of the shelf to near Cape Hatteras. Density gradients limit exchange with adjacent water masses. The similarity of inorganic nutrient, chlorophyll and DOM concentrations in the "cold pool" with other shelf waters, however, indicates that processes occurring in adjacent water influence it.

The concentrations of DOC, DON and DOP measured in this study in estuarine, shelf and slope waters are within the ranges previously reported by other investigators for various parts of the MAB and other "coastal" waters (Chen et al., 1996; Hopkinson et al., 1997; Vlahos et al., 1998, 2002; Bates and Hansell, 1999; Bauer et al., 2000; Bauer et al., 2002). The pattern of elevated concentrations in surface waters relative to deep water and inner shelf relative to outer shelf is a typical, recurring pattern. Surface concentrations of DOM were all in excess of those typically found in the open ocean (Sharp et al., 1993) indicating either substantial authochthonous production or allochthonous inputs from rivers and estuaries along the MAB. DOC and DON concentrations were inversely proportional to salinity $\left(R^{2}=0.7\right.$ and 0.64 , respectively), suggesting that freshwater from rivers or estuaries was an important source of elevated DOM. It is also possible however that autochthonous DOM production was higher in low-salinity water as a result of riverine inputs of nutrients. Neither DOC, DON nor DOP concentrations were correlated with chlorophyll $a$ concentrations; however, a correlation might be expected if autochthonous production was the major source of elevated DOM concentrations in lower-salinity water.

Dissolved organic matter $\mathrm{C}: \mathrm{N}: \mathrm{P}$ ratios were substantially depleted in $\mathrm{N}$ and $\mathrm{P}$ relative to the Redfield ratio (106:16:1) (Table 2). C:N:P ratios were substantially higher in the deep-water samples (4404:360:1 and 986:70.5:1 in March and
Table 2

Initial DOM concentrations and C:N:P stoichiometry

\begin{tabular}{lrrll}
\hline Date Stn. Name DOC $(\mu \mathrm{M})$ & DON $(\mu \mathrm{M})$ DOP $(\mu \mathrm{M}) \mathrm{C}: \mathrm{N}: \mathrm{P}$ \\
\hline March 1996 & & & & \\
T1S1 & 114 & 8.98 & 0.32 & $356: 28.1: 1$ \\
T1S4 & 81 & 8.95 & 0.28 & $290: 32.0: 1$ \\
T2S1 & 104 & 8.8 & 0.25 & $415: 35.3: 1$ \\
T3S1 & 161 & 12.2 & 0.37 & $437: 32.9: 1$ \\
T3S4 & 92 & 8.7 & 0.28 & $329: 31.1: 1$ \\
T4S1 & 113 & 10.3 & 0.29 & $391: 35.4: 1$ \\
T4S7 & 44 & 3.6 & 0.01 & $4404: 360: 1$ \\
T5S1 & 143 & 12.6 & 0.42 & $340: 29.9: 1$ \\
T5S4 & 111 & 7.9 & 0.25 & $445: 31.5: 1$ \\
T6S1 & 115 & 11.1 & 0.28 & $410: 39.6: 1$ \\
ChesBay & 115 & 10.9 & 0.32 & $359: 34.2: 1$ \\
August 1996 & & & & \\
T1S1 & 100 & 8.2 & 0.32 & $312: 25.8: 1$ \\
T1S4 & 94 & 7.1 & 0.27 & $349: 26.4: 1$ \\
T2S1 & 117 & 9.7 & 0.28 & $419: 34.6: 1$ \\
T3S1 & 120 & 11.3 & 0.3 & $398: 37.7: 1$ \\
T3S4 & 109 & 9.3 & 0.25 & $436: 37.1: 1$ \\
T4S1 & 136 & 10.7 & 0.26 & $525: 41.2: 1$ \\
T4S7 & 49 & 3.5 & 0.05 & $986: 70.5: 1$ \\
T5S1 & 201 & 14.3 & 0.35 & $574: 40.9: 1$ \\
T5S4 & 123 & 10.2 & 0.37 & $332: 27.6: 1$ \\
T5S5 & 128 & 9.8 & 0.32 & $401: 30.5: 1$ \\
T6S1 & 154 & 12.1 & 0.14 & $1101: 86.7: 1$ \\
\hline
\end{tabular}

August, respectively, for deep slope water at station T4S7). For shelf samples, $\mathrm{C}: \mathrm{N}$ ratios ranged from 9.1 to $14.1: 1$ between stations and over time. C:P ratios varied between 290 and 1101:1. N:P ratios ranged from 25.8 and 86.7:1 across stations in March and August. Substantial deviation from Redfield ratios for coastal and oceanic DOM has been observed previously (Jackson and Williams, 1985; Williams, 1995; Hopkinson et al., 1997; Björkman et al., 2000; Karl et al., 2001) and appears to be the general pattern. Increased deviation from Redfield with depth also appears to be the general oceanic pattern. Ratios of $\mathrm{C}$ to $\mathrm{N}$ for the high molecular weight (HMW) portion of DOM ( > 1000 Da) have been reported for the MAB, and in general are higher than we observed for the bulk DOM. High molecular weight DOC:N ratios averaged 15:1 (range 11-23) in surface water and 18.5:1 (range 14-24) for MAB bottom water (Mitra et al., 2000). That the C:N ratio for HMW DOM is higher than 
for bulk DOM suggests that the low-molecular weight fraction (which typically comprises $\sim 70 \%$ of total DOC) must have a C:N closer to Redfield.

\subsection{Incubation time courses}

We found two patterns of DOM decomposition that were representative of all stations, one for deep slope water and another for shelf waters (Fig. 2). As was expected, there were no significant changes over time in any constituent measured in the slope water incubations. Thus, these stations provide an indication of the "cleanliness" of our incubation technique. Poor technique, such as dirty glassware or contamination during sampling, would have resulted in high variability over time or in significant temporal decreases in DOM due to introduction of labile organic matter. The
DOM concentration variability that we observed over 180-day incubations of slope water is primarily due to methodological or instrument precision; this sets the limit to the sensitivity of the incubation technique for assessing DOM decomposition rates.

All shelf water samples experienced substantial decreases in DOC, DON and DOP concentrations over time in a manner similar to that portrayed for Station T3S4 from March 1996 (Fig. 2). DOM concentrations decreased over time but at ever decreasing rates. DOM was never completely consumed for $\mathrm{C}, \mathrm{N}$ or $\mathrm{P}$.

\subsection{Decomposition model}

The three-pool, multi-G model described the temporal changes in DOM concentration
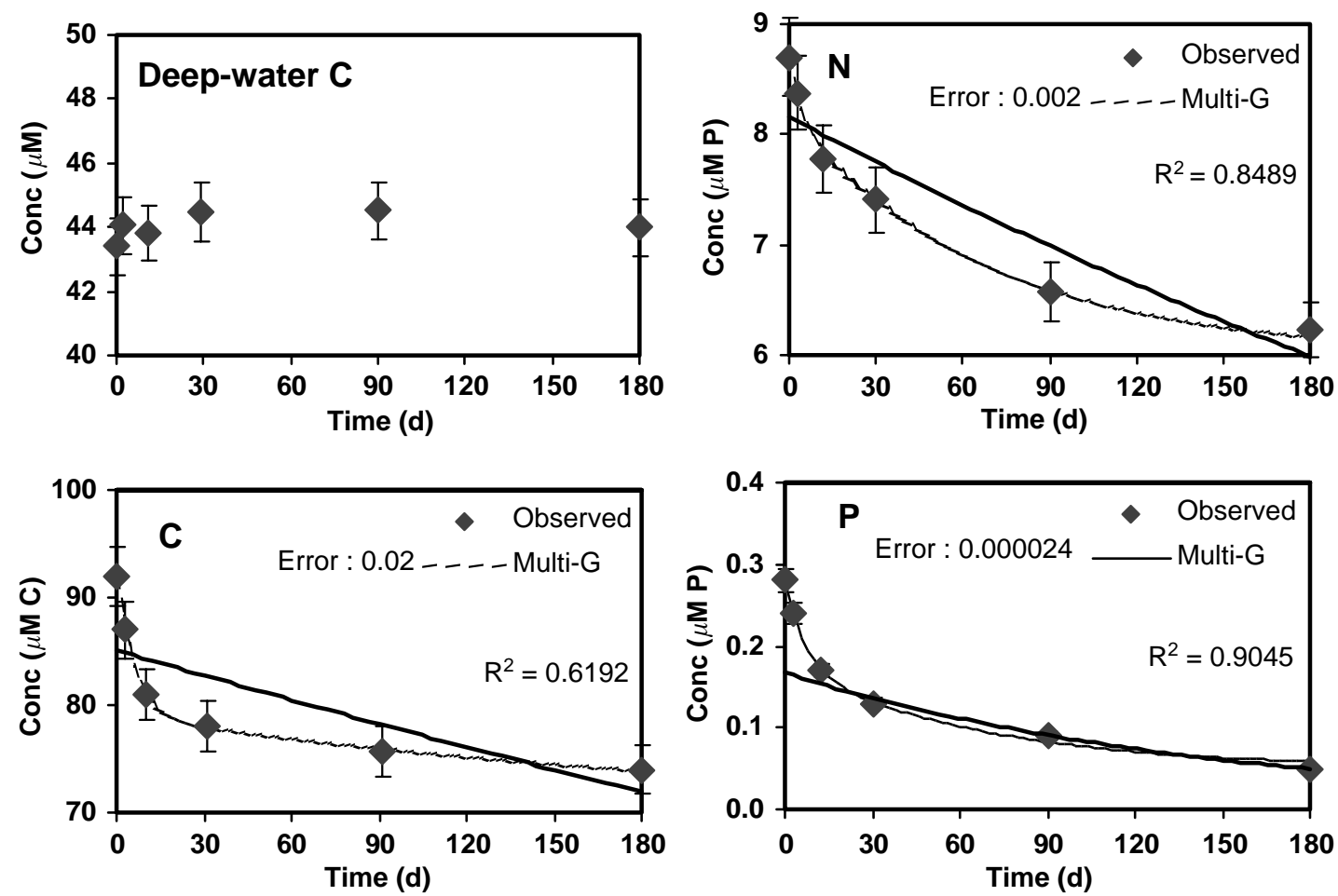

Fig. 2. Representative data on DOC, DON and DOP concentrations during 180-day incubations of MAB water. Data from deepwater station, T4S7, illustrates its recalcitrant nature and the "cleanliness" of our technique (vertical bars denote standard deviation). Panels marked C, N or P are from station T3S4. Dashed lines connecting observations were predicted from the multi-G model. The mean error squared for the multi-G model is indicated for each curve. For contrast, the more commonly used, simple, one-pool exponential fit to the data is also shown along with its respective $R^{2}$ (solid line). 
extremely well, as indicated by the very low mean squared error for each incubation time series (data not listed). The multi-G model described the data much better than a single pool exponential model. As an example consider the results for the T3S4 station in March (Fig. 2). Whereas the simple exponential model fit the data reasonably well, as indicated by $R^{2}$ values of $0.61,0.85$ and 0.91 , respectively, for $\mathrm{C}, \mathrm{N}$ and $\mathrm{P}, R^{2}$ values for the multi-G model, calculated by regressing predicted against observed values, were $0.999^{+}$for $\mathrm{C}, \mathrm{N}$ and P. In fact, there was close agreement between predicted and observed data for all stations, with $R^{2}$ exceeding 0.99 for $\mathrm{C}, \mathrm{N}$ and $\mathrm{P}$ (Fig. 3). Visually the multi-G model was also far superior. When time course data indicate a substantial undegraded fraction remaining after incubation, a model with at least two pools, labile and recalcitrant fractions, is probably more appropriate than a single pool model.

The excellent fit of the multi-G model to our data indicates that bulk DOM can be described as consisting of three components of differing size and degrees of decomposability: a very labile DOM pool $\left(\mathrm{M}_{1}\right)$, a labile DOM pool $\left(\mathrm{M}_{2}\right)$, and a recalcitrant DOM pool $\left(\mathrm{M}_{3}\right)$ for which a decomposition rate cannot be assessed with the methodology employed.

\subsection{DOM pools}

The Marquardt fitting routine provided estimates of the size of each of the DOM pools (Table 3). Deep slope water DOM concentrations did not change over time; deep-water DOM is, by definition, classified as recalcitrant material. The size of the recalcitrant DOC, DON and DOP pools in slope water was similar in March and August: $\mathrm{C}_{3}: 44-49 \mu \mathrm{M}, \mathrm{N}_{3}: 1.6-2.1 \mu \mathrm{M}, \mathrm{P}_{3}: 0.01-0.009 \mu \mathrm{M}$.

For shelf water, dissolved organic carbon was dominated by recalcitrant material in March and August. It averaged $86 \mu \mathrm{M} \mathrm{C}$, ranging from 64 to $141 \mu \mathrm{M}$ (excluding deep water). Very labile and labile DOC pools were much smaller in magnitude, averaging 20.4 and $15.2 \mu \mathrm{M} \mathrm{C}$. Both pools varied considerably between sample locations, with very labile DOC ranging between 3.9 and $56 \mu \mathrm{M} \mathrm{C}$ and labile DOC ranging between 4.9 and $27.3 \mu \mathrm{M} \mathrm{C}$.
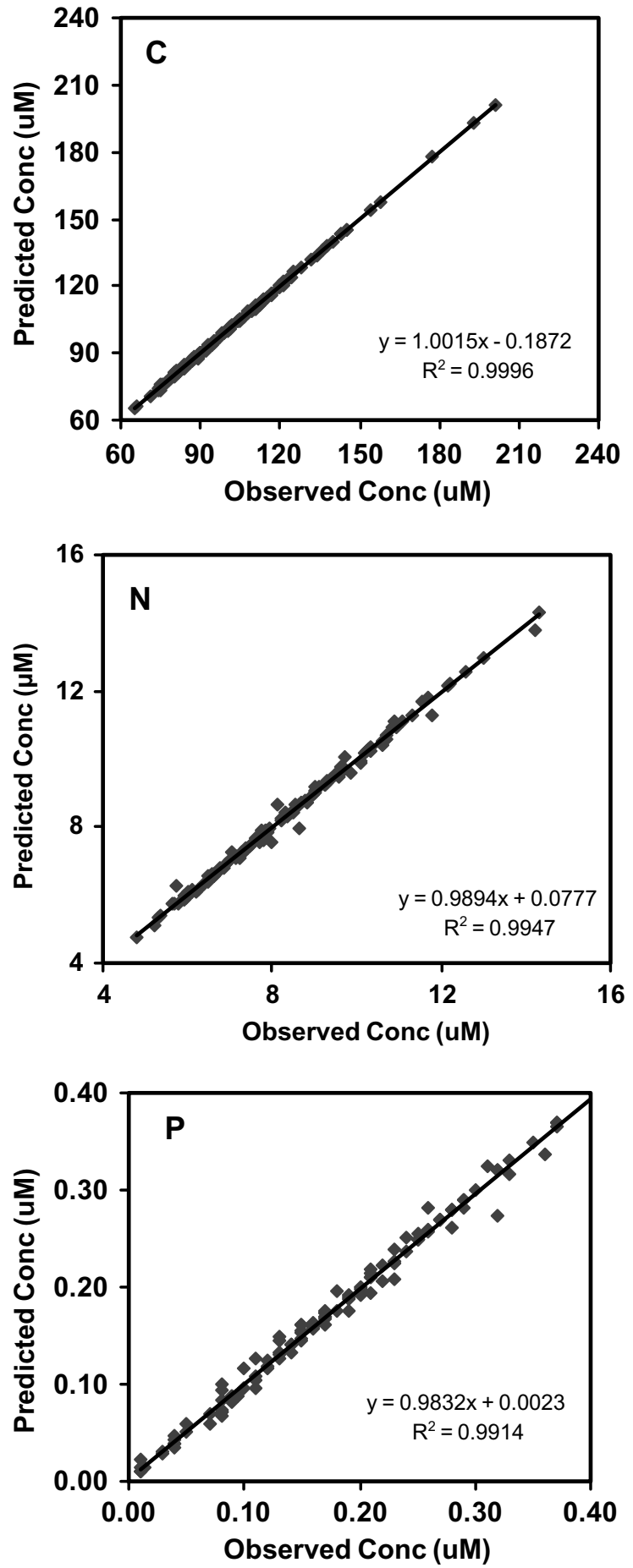

Fig. 3. Relationship between observed concentrations of DOC, DON and DOP and those predicted from the multi-G model. 
Table 3

Pool sizes of very labile $\left(\mathrm{M}_{1}\right)$, labile $\left(\mathrm{M}_{2}\right)$ and recalcitrant $\left(\mathrm{M}_{3}\right)$ DOC, DON and DOP from a variety of locations along the Middle Atlantic Bight and deep slope water in March and August as determined from fitting decomposition data to a three-pool decomposition model using a Marquardt fitting routine

\begin{tabular}{|c|c|c|c|c|c|c|c|c|c|}
\hline & \multicolumn{3}{|c|}{ DOC } & \multicolumn{3}{|c|}{ DON } & \multicolumn{3}{|l|}{ DOP } \\
\hline & {$\left[\mathrm{C}_{1}\right]$} & {$\left[\mathrm{C}_{2}\right]$} & {$\left[\mathrm{C}_{3}\right]$} & {$\left[\mathrm{N}_{1}\right]$} & {$\left[\mathrm{N}_{2}\right]$} & {$\left[\mathrm{N}_{3}\right]$} & {$\left[\mathrm{P}_{1}\right]$} & {$\left[\mathrm{P}_{2}\right]$} & {$\left[\mathrm{P}_{3}\right]$} \\
\hline \multicolumn{10}{|c|}{ August } \\
\hline T1S1 & 5.7 & 21.1 & 73 & 1.15 & 1.29 & 5.80 & 0.152 & 0.108 & 0.060 \\
\hline T1S4 & 13.4 & 4.9 & 76 & 0.52 & 1.40 & 5.20 & 0.066 & 0.152 & 0.052 \\
\hline $\mathrm{T} 2 \mathrm{~S} 1$ & 19.9 & 16.3 & 81 & 2.67 & 2.00 & 5.03 & 0.099 & 0.155 & 0.026 \\
\hline $\mathrm{t} 3 \mathrm{~S} 1$ & 18.4 & 19.1 & 82 & 3.51 & 2.00 & 5.79 & 0.092 & 0.138 & 0.070 \\
\hline T3S4 & 9.3 & 13.7 & 86 & 1.08 & 1.60 & 6.60 & 0.069 & 0.179 & 0.002 \\
\hline $\mathrm{T} 4 \mathrm{~S} 1$ & 31.3 & 7.2 & 98 & 1.22 & 2.00 & 7.50 & 0.000 & 0.176 & 0.085 \\
\hline T5S1 & 54.1 & 5.8 & 141 & 2.17 & 4.14 & 8.00 & 0.143 & 0.107 & 0.100 \\
\hline T5S4 & 31.4 & 18.3 & 73 & 2.13 & 3.30 & 4.80 & 0.147 & 0.123 & 0.100 \\
\hline T5S5 & 23.5 & 17.7 & 87 & 0.00 & 2.40 & 7.70 & 0.160 & 0.089 & 0.071 \\
\hline T6S1 & 12.9 & 27.3 & 114 & 2.09 & 2.20 & 7.85 & 0.120 & 0.011 & 0.009 \\
\hline $\mathrm{T} 4 \mathrm{~S} 7$ & 0.0 & 0.0 & 49 & 0.00 & 0.00 & 2.06 & 0.000 & 0.000 & 0.050 \\
\hline \multicolumn{10}{|l|}{ March } \\
\hline T1S1 & 27.1 & 12.9 & 74 & 1.77 & 1.15 & 6.06 & 0.139 & 0.041 & 0.140 \\
\hline T1S4 & 3.9 & 13.4 & 64 & 0.54 & 3.31 & 5.10 & 0.152 & 0.108 & 0.020 \\
\hline $\mathrm{T} 2 \mathrm{~S} 1$ & 12.8 & 13.9 & 77 & 1.46 & 0.96 & 6.40 & 0.127 & 0.103 & 0.020 \\
\hline $\mathrm{T} 3 \mathrm{~S} 1$ & 56.0 & 22.5 & 83 & 4.15 & 1.14 & 6.90 & 0.020 & 0.290 & 0.060 \\
\hline T3S4 & 12.9 & 9.1 & 70 & 0.55 & 2.16 & 6.00 & 0.103 & 0.127 & 0.050 \\
\hline $\mathrm{T} 4 \mathrm{~S} 1$ & 23.7 & 5.3 & 81 & 2.67 & 1.99 & 5.60 & 0.063 & 0.197 & 0.030 \\
\hline T5S1 & 13.4 & 10.2 & 119 & 2.91 & 2.65 & 7.00 & 0.050 & 0.300 & 0.070 \\
\hline T5S4 & 17.9 & 18.3 & 75 & 0.22 & 3.15 & 4.50 & 0.070 & 0.170 & 0.010 \\
\hline T6S1 & 5.4 & 22.4 & 87 & 1.80 & 3.28 & 6.00 & 0.015 & 0.230 & 0.035 \\
\hline Ches & 12.5 & 24.4 & 78 & 2.74 & 3.20 & 5.00 & 0.010 & 0.230 & 0.080 \\
\hline T4S7 & 0.0 & 0.0 & 44 & 0.00 & 0.30 & 1.60 & 0.000 & 0.000 & 0.010 \\
\hline
\end{tabular}

All units are $\mu \mathrm{M}$. nd indicates not determined.

On average, DOC was $16 \%$ very labile, $13 \%$ labile and $71 \%$ recalcitrant.

DON was also dominated by recalcitrant material in both August and March. $\mathrm{DON}_{3}$ averaged $6.1 \mu \mathrm{M} \mathrm{N}$ in magnitude, which is equivalent to about $61 \%$ of the total DON pool. Both labile DON pools varied considerably between stations, with $\mathrm{DON}_{1}$ ranging from 0 to $4.15 \mu \mathrm{M} \mathrm{N}$ and $\mathrm{DON}_{2}$ ranging from 1.14 to $4.14 \mu \mathrm{M}$ N. Spatial variation in labile pool sizes was far greater than the relatively small changes in mean pool sizes between March and August. On average, DON was $17 \%$ very labile, $22 \%$ labile and $61 \%$ recalcitrant.

DOP pool sizes were considerably different from DON and DOC. Unlike the latter, the recalcitrant DOP pool was typically the smallest of the three pools. $\mathrm{DOP}_{3}$ ranged from $0.002-0.10 \mu \mathrm{M} \mathrm{P}$ and averaged $0.06 \mu \mathrm{M}$. The largest DOP pool was the labile material (ranging from $0.011-0.3 \mu \mathrm{M}$ ); very labile material ranged from undetectable to $0.16 \mu \mathrm{M}$. As with DON, there were minor differences in pool sizes between March and August on average. On average, DOP was $32 \%$ very labile, $50 \%$ labile and $17 \%$ recalcitrant.

Striking differences were noted in the relative sizes of decomposable (including both $\mathrm{M}_{1}$ (very labile) and $\mathrm{M}_{2}$ (labile)) and recalcitrant pools of DOC, DON and DOP (Fig. 4). The decomposable pool comprised only $29 \%$ of the DOC pool, while it comprised $83 \%$ of the DOP pool. The decomposable DON pool made up a slightly larger fraction of the total DON pool than did the decomposable DOC pool, $39 \%$ of the total. The recalcitrant pools showed the opposite pattern, with recalcitrant DOP comprising only $17 \%$ of the 
DOC



86.0

DON

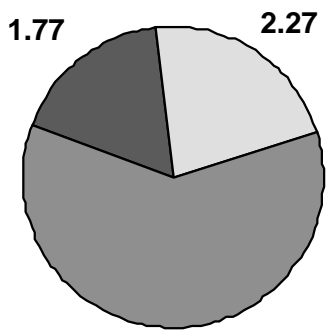

6.14

$\square$ Very Labile $\square$ Labile $\square$ Recalcitrant

DOP
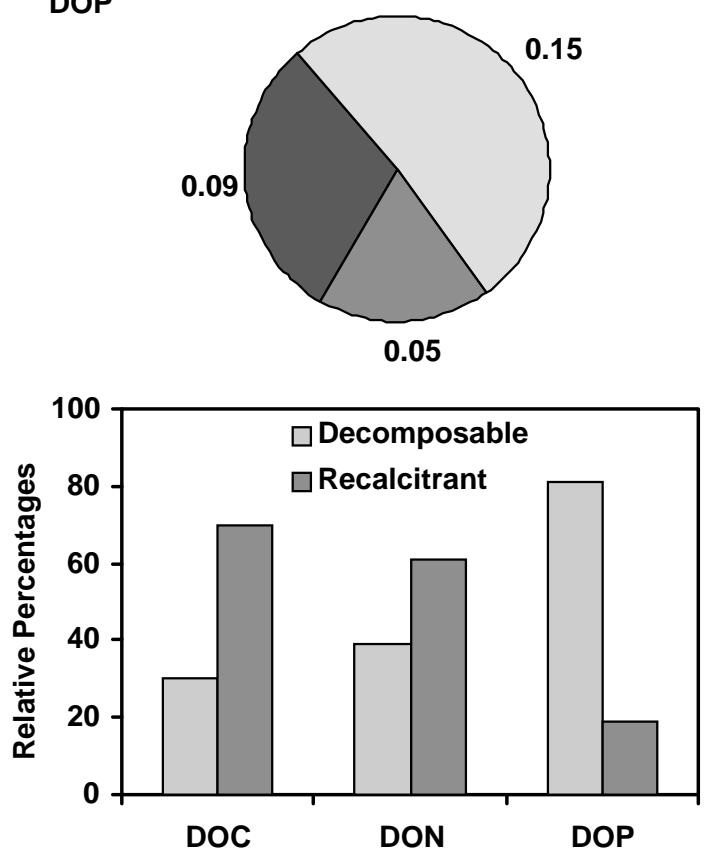

Fig. 4. Pie charts: average sizes of very labile $\left(\mathrm{C}_{1}\right)$, labile $\left(\mathrm{C}_{2}\right)$, and recalcitrant $\left(\mathrm{C}_{3}\right)$ pools within the bulk DOC, DON and DOP pools in March and August. Units $-\mu \mathrm{M}$. Bar chart: relative percentages of decomposable (sum of very labile and labile pools) and recalcitrant portions of bulk DOC, DON and DOP in March and August. total, $\mathrm{N}_{3}$ comprising $61 \%$ and $\mathrm{C}_{3}$ comprising $71 \%$ of the total pool.

As was seen for total DOC and DON, concentrations of decomposable $\left(\mathrm{M}_{1}+\mathrm{M}_{2}\right)$ DOC and DON and recalcitrant $\left(\mathrm{M}_{3}\right)$ DOC and DON also demonstrated an inverse relation to salinity $\left(R^{2}=0.27,0.40,0.83,0.55\right.$, respectively). None of the DOP fractions, including the bulk pool, was significantly correlated with salinity. On a relative basis, for $\mathrm{C}$ and $\mathrm{N}$, the percentage of recalcitrant DOM tended to increase while the percentage of decomposable DOM decreased with increasing salinity. The opposite pattern was observed for DOP, where the percentage of decomposable DOP $\left(\mathrm{P}_{1}+\mathrm{P}_{2}\right)$ increased with increasing salinity. As noted for the bulk DOC and DON pools, the various DOM pools were not correlated with chlorophyll concentration. As DOC production is often considered to be linked to primary production through algal exudates, zooplankton sloppy feeding, viral lysis, etc., correlation between DOM concentration and chlorophyll standing crop might be expected. However, there is often asynchrony between chlorophyll standing crops and primary production and between algal exudation and the phase of bloom development (Norrman et al., 1995). Thus for a system as heterogeneous as the MAB, the lack of correlation probably indicates that chlorophyll is not a good predictor of the various processes that contribute to the size of the different DOM pools.

There is little information in the literature on the relative sizes of decomposable and recalcitrant DOM pool sizes. This is primarily attributable to the slow development of instrumentation and methodology adequate for detecting extremely slow rates of DOM decay. Some studies of DOC lability are based on measures of dissolved oxygen consumption and initial DOC concentration. Other studies are based on the apparent age of DOC as determined from ${ }^{14} \mathrm{C}$ analysis (Williams and Druffel, 1987; Bauer et al., 1992). Still others are based on deep-ocean gradients between the North Atlantic and North Pacific (Hansell and Carlson, 1998). Analysis of DON and DOP is still based on the difference in measures of total dissolved pools and inorganic pools and precision suffers as a result. There has also been much more 
interest in DOC than in DON and DOP. Nevertheless, it appears that the relative size of the decomposable DOC pool in the MAB (range of $19-49 \%)$ is somewhat large relative to other aquatic systems, where decomposable DOC averages $17-30 \%$ of the bulk pool (Barber, 1968; Ogura, 1972; Skopintsev, 1976; Romankevich, 1984; Søndergaard and Middelboe, 1995; Carlson and Ducklow, 1996; Hopkinson et al., 1997; Moran et al., 1999, 2000). Our results differ substantially from those of Raymond and Bauer (2000) and Moran et al. (1999), who found on average only $7-8 \%$ of DOC to be decomposable. Their studies were conducted in river-dominated estuaries, however, and the smaller decomposable fraction may reflect a large recalcitrant, humic fraction derived from terrestrial soils. Uhlenhopp et al. (1995) found that only $10-20 \%$ of DOC in streams draining urban, forested and agricultural land covers was decomposable. Thus, it would appear that DOC on continental shelves is generally more degradable than that in many "terrestrially dominated" aquatic systems. Presumably this reflects a decreased importance of terrestrial humic compounds and an increased importance of autochthonous, algal-derived material as has been shown in geochemical studies across coastal gradients (see for e.g., Hedges, 1992). However, as Søndergaard and Middelboe (1995) concluded, the evidence for a "terrestrial" relationship is weak and needs further exploration. We are unaware of comparable decomposition studies for DON and DOP in the ocean to which to compare results. Our results for DOP, however, greatly contrast those for a shallow, eutrophic lake. Cooper et al. (1991) observed only $12 \%$ loss of DOP in a 30-day incubation, whereas in our study $56-99 \%$ of the DOP was mineralized during incubation. We lack sufficient information to conclude whether the difference between continental shelf and lake DOP decomposability reflects the importance of soil-derived humics.

It should be noted that the classification of various DOM pools with a characteristic lability is a product of our methodology and approach. In reality DOM is composed of an unknown number of individual compounds, each with a different lability. Thus DOM represents a continuum of biological lability from refractory material turning over on time scales of millennia to very labile material turning over on time scales of minutes (Carlson, 2002). The cross-deep-ocean DOC gradient of $14 \mu \mathrm{M}$ and a thermohaline circulation time in excess of several thousand years indicates that even the most refractory, deep-ocean DOC (typically $40-45 \mu \mathrm{M}$ ) turns over on a time scale of $10^{3}-10^{4} \mathrm{yr}$ (Hansell and Carlson, 1998). The definition of recalcitrant in our study (e.g., $114 \mu \mathrm{M}$ at $\mathrm{T} 6 \mathrm{~S} 1)$ is quite different than the recalcitrant described in the Hansell and Carlson study. Clearly there are no laboratory analytical techniques available to detect DOC changes as small as $14 \mu \mathrm{M}$ per thousand years $\left(<0.014 \mu \mathrm{M} \mathrm{yr}^{-1}\right)$.

\subsection{DOM decomposition rate constants}

Decay coefficients for DOM decomposition fell into two general groupings, one for very labile pools and another for labile pools, which were similar for DOC, DON and DOP (Fig. 5 and Table 4). The overall mean decay rate for the very labile $\mathrm{C}, \mathrm{N}$ and $\mathrm{P}$ pools was $0.219 \mathrm{~d}^{-1}$. The mean overall decay rate for the labile pools was an order of magnitude lower at $0.018 \mathrm{~d}^{-1}$. There was a great deal of variability in decay rates from station to station. For instance, the range of decay rates for the very labile DOC pool $\left(k_{1}\right)$ ranged from 0.05 to $1.51 \mathrm{~d}^{-1}$. Most of the variability was attributable



Fig. 5. Average decay constants for very labile $\left(k_{1}\right)$ and labile $\left(k_{2}\right)$ DOC, DON and DOP from the middle Atlantic bight in March and August. Error bars refer to standard deviation. 
Table 4

Decay coefficients for the very labile and labile DOC, DON and DOP pools from a variety of locations along the Middle Atlantic Bight and deep slope water in March and August as determined from fitting decomposition data to a three-pool decomposition model using a Marquardt fitting routine

\begin{tabular}{|c|c|c|c|c|c|c|}
\hline & \multicolumn{2}{|l|}{ DOC } & \multicolumn{2}{|l|}{ DON } & \multicolumn{2}{|l|}{ DOP } \\
\hline & $K_{1}$ & $k_{2}$ & $k_{1}$ & $k_{2}$ & $k_{1}$ & $K_{2}$ \\
\hline \multicolumn{7}{|l|}{ August } \\
\hline T1S1 & 1.5125 & 0.01890 & 0.0890 & 0.00190 & 0.1582 & 0.00218 \\
\hline T1S4 & 0.1267 & 0.00943 & 0.7682 & 0.00263 & 0.6524 & 0.00338 \\
\hline $\mathrm{T} 2 \mathrm{~S} 1$ & 0.4660 & 0.02500 & 0.1628 & 0.00424 & 0.1674 & 0.00508 \\
\hline $\mathrm{t} 3 \mathrm{~S} 1$ & 0.1883 & 0.00724 & 0.0964 & 0.01070 & 0.0847 & 0.00370 \\
\hline T3S4 & 0.1091 & 0.01367 & 0.0738 & 0.00330 & 0.2000 & 0.01470 \\
\hline $\mathrm{T} 4 \mathrm{~S} 1$ & 0.1213 & 0.01260 & 0.0274 & 0.02330 & 0.1200 & 0.02270 \\
\hline T5S1 & 0.0500 & 0.00577 & 0.0721 & 0.00543 & 0.0608 & 0.00408 \\
\hline T5S4 & 0.4192 & 0.2320 & 0.0108 & 0.00572 & 0.1412 & 0.00328 \\
\hline T5S5 & 0.1217 & 0.01344 & 0.0683 & 0.03176 & 0.0821 & 0.00530 \\
\hline T6S1 & 0.3264 & 0.01420 & 0.0815 & 0.00506 & 0.0731 & 0.01030 \\
\hline $\mathrm{T} 4 \mathrm{~S} 7$ & 0.0000 & 0.0000 & 0.0000 & 0.00000 & 0.00000 & 0.00000 \\
\hline \multicolumn{7}{|l|}{ March } \\
\hline T1S1 & 0.2136 & 0.01270 & 0.0582 & 0.0582 & 0.1850 & 0.11710 \\
\hline T1S4 & 0.1659 & 0.02703 & 0.2377 & 0.2377 & 0.1570 & 0.01800 \\
\hline $\mathrm{T} 2 \mathrm{~S} 1$ & 0.2044 & 0.00940 & 0.0619 & 0.0619 & 0.3772 & 0.00860 \\
\hline $\mathrm{T} 3 \mathrm{~S} 1$ & 0.2245 & 0.02405 & 0.1000 & 0.1000 & 0.0088 & 0.03615 \\
\hline T3S4 & 0.1642 & 0.00470 & 0.2574 & 0.2574 & 0.1500 & 0.01510 \\
\hline T4S1 & 0.1478 & 0.01800 & 0.0300 & 0.0300 & 0.3000 & 0.01760 \\
\hline T5S1 & 0.2143 & 0.09220 & 0.1800 & 0.1800 & 0.3339 & 0.03280 \\
\hline T5S4 & 0.1775 & 0.04230 & 0.2134 & 0.2134 & 0.1700 & 0.02990 \\
\hline T6S1 & 0.6578 & 0.02050 & 0.1258 & 0.1258 & 0.5000 & 0.04310 \\
\hline Ches & 0.1500 & 0.01088 & 0.0592 & 0.0592 & 0.6950 & 0.05280 \\
\hline T4S7 & 0.0000 & 0.00000 & 0.0000 & 0.0000 & 0.0000 & 0.00000 \\
\hline
\end{tabular}

Units are $\mathrm{d}^{-1}$.

to four of the 22 water samples analyzed. As a result of the high variability, there were no discernible differences in decay coefficients between time of year or between DOC, DON and DOP that were statistically significant. The high variability was not explained by any of the variables we measured, including $\mathrm{C}: \mathrm{N}: \mathrm{P}$ stoichiometry, salinity, or inorganic nutrient concentrations. We found little relation between DOM decay coefficients and chlorophyll concentrations. Generally decomposition rates were not significantly related to any of the DOM pool sizes, although $14 \%$ of the variation in $k_{2}$ for DON could be explained by the pool size of labile DON $\left(R^{2}=0.14, P<0.05\right)$.

These calculations of decay coefficients should be considered approximations to rates actually observed in the MAB. Incubations were conducted at room temperature, and the extended incubations undoubtedly resulted in extensive modifications of the biotic community. Additional processes such as photo-degradation may enhance DOC susceptibility to microbial breakdown (Moran et al., 1999; Mopper et al., 1991). With these caveats in mind, it is still useful to compare results to other studies and to other processes occurring on the continental shelf with similar time scales.

While there have been a number of decomposition studies conducted over the past $60 \mathrm{yr}$, decomposition rate constants were seldom reported. Those few studies that did report rate constants used an approach that did not differentiate between labile and recalcitrant pools. This is not to imply that other investigators have not conceptualized DOM as having pools of varying 
Table 5

Half-lives $\left(t_{1 / 2}=d\right)$ of very labile, and labile DOC, DON and DOP from a variety of locations along the Middle Atlantic Bight and deep slope water in March and August as determined from fitting decomposition data to a three-pool decomposition model using a Marquardt fitting routine

\begin{tabular}{|c|c|c|c|c|c|c|}
\hline & \multicolumn{2}{|l|}{ DOC } & \multicolumn{2}{|l|}{ DON } & \multicolumn{2}{|l|}{ DOP } \\
\hline & {$\left[\mathrm{C}_{1}\right]-t_{1 / 2}$} & {$\left[\mathrm{C}_{2}\right]-t_{1 / 2}$} & {$\left[\mathrm{~N}_{1}\right]-t_{1 / 2}$} & {$\left[\mathrm{~N}_{2}\right]-t_{1 / 2}$} & {$\left[\mathrm{P}_{1}\right]-t_{1 / 2}$} & {$\left[\mathrm{P}_{2}\right]-t_{1 / 2}$} \\
\hline \multicolumn{7}{|c|}{ August } \\
\hline T1S1 & 0 & 37 & 8 & 365 & 4 & 318 \\
\hline T1S4 & 5 & 73 & 1 & 263 & 1 & 205 \\
\hline $\mathrm{T} 2 \mathrm{~S} 1$ & 1 & 28 & 4 & 163 & 4 & 136 \\
\hline t3S1 & 4 & 96 & 7 & 65 & 8 & 187 \\
\hline $\mathrm{T} 3 \mathrm{~S} 4$ & 6 & 51 & 9 & 210 & 3 & 47 \\
\hline $\mathrm{T} 4 \mathrm{~S} 1$ & 6 & 55 & 25 & 30 & 6 & 31 \\
\hline T5S1 & 14 & 120 & 10 & 128 & 11 & 170 \\
\hline T5S4 & 2 & 30 & 64 & 121 & 5 & 211 \\
\hline T5S5 & 6 & 52 & 10 & 22 & 8 & 131 \\
\hline $\mathrm{T} 6 \mathrm{~S} 1$ & 2 & 49 & 9 & 137 & 9 & 67 \\
\hline $\mathrm{T} 4 \mathrm{~S} 7$ & nd & nd & nd & nd & nd & nd \\
\hline \multicolumn{7}{|c|}{ March } \\
\hline T1S1 & 3 & 55 & 12 & 48 & 4 & 6 \\
\hline T1S4 & 4 & 26 & 3 & 27 & 4 & 39 \\
\hline $\mathrm{T} 2 \mathrm{~S} 1$ & 3 & 74 & 11 & 91 & 2 & 81 \\
\hline $\mathrm{T} 3 \mathrm{~S} 1$ & 3 & 29 & 7 & 74 & 79 & 19 \\
\hline $\mathrm{T} 3 \mathrm{~S} 4$ & 4 & 147 & 3 & 48 & 5 & 46 \\
\hline $\mathrm{T} 4 \mathrm{~S} 1$ & 5 & 39 & 23 & 231 & 2 & 39 \\
\hline T5S1 & 3 & 8 & 4 & 46 & 2 & 21 \\
\hline T5S4 & 4 & 16 & 3 & 47 & 4 & 23 \\
\hline $\mathrm{T} 6 \mathrm{~S} 1$ & 1 & 34 & 6 & 67 & 1 & 16 \\
\hline Ches & 4 & 64 & 12 & 85 & 1 & 13 \\
\hline $\mathrm{T} 4 \mathrm{~S} 7$ & nd & nd & nd & nd & nd & nd \\
\hline
\end{tabular}

nd indicates not determined.

lability. Connolly et al. (1992) modeled bacterial utilization of DOC with reasonable success using a two-step process with two different half-saturation constants and super-labile and just labile DOC pools. Ogura (1972) conceptualized a three-pool model similar to ours but obtained rate constants differently. Ogura reported rate constants between 0.01 and $0.09 \mathrm{~d}^{-1}$ for the very labile pool and an order of magnitude lower for the labile pool. Others who calculated rate constants by assuming a single labile pool and no recalcitrant background have reported substantially longer rate constants (Hopkinson et al., 1997; Moran et al., 1999; Raymond and Bauer, 2000) for estuarine and coastal waters. It is improper to compare rates calculated from models with contradictory assumptions.

\subsection{Half-lives of shelf DOM}

Half-lives of the very labile and labile DOC, DON and DOP pools, calculated from the decay coefficients, also fell into two groupings, with little difference between $\mathrm{C}, \mathrm{N}$ and $\mathrm{P}$ (Table 5 and Fig. 6). Very labile DOM pool half-lives ranged from 1-14 days for DOC, from 1 to 64 days for DON, and from 1-79 days for DOP. On average, very labile $\mathrm{C}, \mathrm{N}$ and $\mathrm{P}$ pools half-lives were 4,12 and 8 days. Half-lives of the labile DOM pools were on the order of weeks as opposed to days for the very labile pools. Labile DOM pool half-lives ranged from 8 to 147 days for DOC, from 22 to 365 days for DON and from 6 to 318 days for DOP. The average half-lives of labile DOC, $\mathrm{N}$ and $\mathrm{P}$ were 54, 113 and 90 days. 


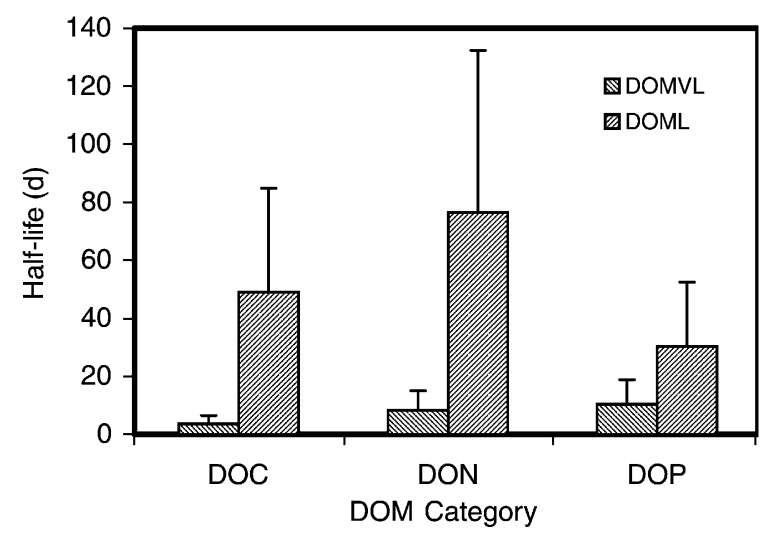

Fig. 6. Average half-lives for very labile (DOMVL) and labile (DOML) pools of DOC, DON and DOP collected from the MAB in March and August. Error bars represent standard deviation.

\subsection{DOM sources}

Data on DOM pool sizes and turnover times relative to shelf-water residence time can be used to infer information about the origin of DOC, DON and DOP on the continental shelf. The very short turnover times of very labile DOC, DON and DOP (4-12 days) indicate that these pools must be of autochthonous origin. The most likely source is DOM production associated with primary production through direct exudation from phytoplankton, from viral-mediated cell lysis, from 'sloppy' zooplankton feeding or from particle solubilization. Based on the average decay constant and pool size of very labile DOC, the average rate of production of very labile DOC is about $5 \mu$ moles $\mathrm{Cl}^{-1} \mathrm{~d}^{-1}$. A reasonable estimate of bacterial production on the shelf is $0.1-0.2 \mathrm{gC} \mathrm{m}^{-2} \mathrm{~d}^{-1}$ (Ducklow, 2000). Assuming 10\% growth efficiency, bacterial $\mathrm{C}$ demand would be approximately $1.5 \mathrm{gC} \mathrm{m}^{-2} \mathrm{~d}^{-1}$. Assuming an average $\mathrm{MAB}$ depth of $30 \mathrm{~m}$, the production of very labile DOC is of sufficient magnitude to support this level of bacterial activity.

The turnover time of the labile DOM pools is on the order of 50-110 days, which is similar to that for shelf water $(\sim 100 \mathrm{~d})$. Thus, the labile pools can be of both autochthonous and allochthonous sources. Fry et al. (1996) showed from a decom- position study of ${ }^{13} \mathrm{C}$-labeled, bloom-derived DOC that about $65-75 \%$ of DOC remaining after the first week of incubation decomposed on the time scale of a year or two. Thus, phytoplankton exudates are one likely autochthonous source of labile material. Rivers are a potential source of labile DOM. Moran et al. (1999) and Raymond and Bauer (2000) showed that approximately $7-$ $8 \%$ of river DOM is decomposable in a $100-d$ timeframe. Other potential sources of labile DOM include recently produced material by phytoplankton external to the shelf. An unknown percentage of labile DOM could originate from terrestrial material that had desorbed from terrestrial mineral surfaces following exposure to marine conditions (Hedges et al., 1997; Kiel et al., 1997).

All of the sources of decomposable DOM are also likely sources of recalcitrant DOM. As Fry et al. (1996) pointed out, 25-25\% of bloomderived DOC remains after $2.5 \mathrm{yr}$. Results from Moran et al. (1999) and Raymond and Bauer (2000) demonstrate that typically more than $90 \%$ of river/estuary-derived DOC remains after longterm incubations. The $\delta^{13} \mathrm{C}$ signature and ${ }^{14} \mathrm{C}$ content of DOC remaining following 1-yr incubations of river/estuarine DOC show that this material is old ( $>500 \mathrm{yr}$ ) and largely of terrestrial origin. The majority of the recalcitrant pool is comprised of the $>1000 \mathrm{yr}$ that makes up ocean deep water (Williams and Druffel, 1987).

\subsection{Preferential remineralization of $P$ and $N$}

Our data clearly demonstrate the preferential remineralization of $\mathrm{P}$ relative to $\mathrm{N}$ and $\mathrm{N}$ relative to C. Whereas $82 \%$ of the DOP pool was remineralized during our 180-d incubations, $39 \%$ of the DON pool and only $30 \%$ of the DOC pool was remineralized. These results are consistent with the general belief that $\mathrm{N}$, not $\mathrm{P}$, is the element most often limiting primary production in ocean and shelf regions. These results support conclusions reached by Jackson and Williams (1985) and Hopkinson et al. (1997) about preferential remineralization of $\mathrm{P}$ that were based on increases in $\mathrm{C}: \mathrm{N}: \mathrm{P}$ ratios of DOM over depth, a proxy for time. These results also indicate that the stoichiometry of DOM remineralization is 
similar to that for particles (Bishop et al., 1977; Martin et al., 1979; Garber, 1984). As with DOM, the $\mathrm{C} / \mathrm{N}$ and $\mathrm{C} / \mathrm{P}$ ratios of sinking particles increase with depth in oceanic ecosystems (Knauer et al., 1979a, b; Martin et al., 1987; Karl et al., 1996).

\subsection{DOM export and the biological pump}

The "biological pump" is a mechanism for removing carbon from the euphotic zone to the deep ocean. Releasing the limiting nutrients ( $N$ and $\mathrm{P}$ ) in the more turbulent waters close to the photic zone results in an efficient $\mathrm{C}$ storage mechanism. Discussions of the biological pump are usually focused on particle sinking. Christian et al. (1997) described the increase with depth of C/ $\mathrm{N}$ and $\mathrm{C} / \mathrm{P}$ ratios of particles (and ratios of upward mixing flux decrease). The relative importance of a dissolved pool flux as a component of total flux is unclear as vertical DOM gradients are typically small. However, Emerson et al. (1995) estimated that $25 \%$ of vertical flux of $\mathrm{C}$ from the euphotic was in the dissolved form. At the Hawaiian Ocean Time Series Station (HOTS) modeling results show a large importance of export from the euphotic zone via downward turbulent mixing of both particulate and dissolved material (Doney et al., 1996). Most DOM is remineralized in the surface aphotic zone but a significant fraction is transported below the depth of the maximum winter mixed layer and thus contributes to the biological pump. Carlson et al. (1994) examined DOC export most directly, concluding that all temperate, sub-polar and continental shelf regions of the world that exhibit convective mixing and vernal restratification export at least as much DOC as POC. Our results for the MAB indicate that substantial amounts of DOM are remineralized in the same time frame as shelf-water residence times and that the remaining DOM is depleted in $\mathrm{N}$ and $\mathrm{P}$ relative to $\mathrm{C}$. Strong concentration gradients in DOM occur between shelf and ocean waters and between surface and deeper waters. Coupled with appropriate vertical and horizontal advective and eddy diffusive transports, DOM export from the MAB may also be significant.

\section{Conclusions}

These studies indicate the heterogeneous nature of bulk DOM and the presence of a variety of discrete pools with a range of decomposability. The proportions of the bulk DOC, DON, and DOP pools that are decomposable differ significantly. These results demonstrate preferential remineralization of $\mathrm{P}$ over $\mathrm{N}$ and $\mathrm{N}$ over $\mathrm{C}$. Turnover times of DOM relative to microbial activity and water residence times on the continental shelf suggest the potential for significant DOM export from the shelf to the ocean, especially for DOC. Better measures of the chemical composition and sources of DOC, DON and DOP will be necessary to resolve a number of questions related to the role of DOM in controlling shelf and ocean stoichiometry, elemental dynamics and metabolism.

\section{Acknowledgements}

This research was funded by grants from the USDOE Ocean Margins Program (DE-Fg0292ER61438.A003) and the National Science Foundation (EAR-9807632 and LTER-OCE-9726921). We thank the crews of the R.V. Endeavor and R.V. Seward Johnson. Ed Rastetter kindly assisted in preparing a Marquardt fitting routine for the three-pool DOC decomposition model. R. Chen provided helpful intercomparison and blank checks on DOC determinations on both cruises. Thanks are extended to Dan Repeta for coordinating cruises.

\section{References}

Barber, R.T., 1968. Dissolved organic carbon from deep water resists microbial oxidation. Nature 220, 274-275.

Bates, N., Hansell, D., 1999. A high resolution study of surface layer hydrographic and biogeochemical properties between Chesapeake Bay and the Sargasso Sea. Nature 357, 667-670.

Bauer, J.E., Druffel, E.R.M., Wolgast, D.M., Griffin, S., 2002. Temporal and regional variability in sources and cycling of DOC and POC in northwest Atlantic continental shelf and slope. Deep-Sea Research II 49 (20), 4387-4419. 
Bauer, J., Druffel, E., 1998. Ocean margins as a significant source of organic matter to the deep open ocean. Nature 392, 482-485.

Bauer, J., Williams, P., Druffel, E., $1992 .{ }^{14} \mathrm{C}$ activity of dissolved organic carbon fractions in the north-central Pacific and Sargasso Sea. Nature 357, 667-670.

Bauer, J., Druffel, E., Wolgast, D., Griffin, S., 2000. Sources and cycling of dissolved and particulate organic radiocarbon in the northwest Atlantic continental margin. Global Biogeochemical Cycles.

Berner, R.A., 1980. Early Diagenesis: a Theoretical Approach. Princeton University Press, Princeton, New Jersey.

Biscaye, P., Flagg, C., Falkowski, P., 1994. The shelf edge exchange process experiment, SEEP-II: an introduction to the hypotheses, results and conclusions. Continental Shelf Research 8, 231-252.

Bishop, J., Collier, R., Ketten, D., Edmond, J., 1977. The chemistry, biology, and vertical flux of particulate matter from the upper $400 \mathrm{~m}$ of the equatorial Atlantic Ocean. Deep-Sea Research 24, 511-548.

Björkman, K., Thomson-Bulldis, A., Karl, D., 2000. Phosphorus dynamics in the North Pacific subtropical gyre. Aquatic Microbial Ecology 22, 185-198.

Carlson, C.A., 2002. Production and consumption processes. In: Hansell, D.A., Carlson, C.A. (Eds.), Biogeochemistry of Dissolved Organic Matter in the Ocean. Academic Press, San Diego, in press.

Carlson, C.A., Ducklow, H., 1996. Growth of bacterioplankton and consumption of dissolved organic carbon in the Sargasso Sea. Aquatic Microbial Ecology 10, 69-85.

Carlson, C., Ducklow, H., Michaels, A., 1994. Annual flux of dissolved organic carbon from the euphtic zone in the Northwestern Sargasso Sea. Nature 371, 405-408.

Chen, R., Fry, B., Hopkinson, C., Repeta, D., Peltzer, E., 1996. Dissolved organic carbon on Georges Bank. Continental Shelf Research 16, 409-420.

Cherrier, J., Bauer, J., Druffel, E., 1996. Utilization and turnover of labile dissolved organic matter by bacterial heterotrophs in eastern north Pacific surface waters. Marine Ecology Progress Series 139, 267-279.

Christian, J., Lewis, M., Karl, D., 1997. Vertical fluxes of carbon, nitrogen, and phosphorus in the North Pacific Subtropical gyre near Hawaii. Journal of Geophysical Research 102, 15667-15677.

Coffin, R., Connolly, J., Harris, P., 1993. Availability of dissolved organic carbon to bacterioplankton examined by oxygen utilization. Marine Ecology Progress Series 101, 9-22.

Connolly, J., Coffin, R., Landeck, R., 1992. Modeling carbon utilization by bacteria in natural water systems. In: Hurst, C. (Ed.), Modeling the Metabolic and Physiologic Activities of Microorganisms. Wiley, New York, pp. 249-276, 300pp.

Cooper, J., Early, J., Holding, A., 1991. Mineralization of DOP from a shallow eutrophic lake. Hydrobiologia 209, 89-94.

Doney, S., Glover, D., Najjar, R., 1996. A new coupled 1-d model for the upper ocean. Deep-Sea Research 43, 591-624.
Ducklow, H., 2000. Bacterial production and biomass in the oceans. In: Kirchman, D. (Ed.), Microbial Ecology of the Oceans. Wiley, New York, pp. 85-120, 542pp.

Ducklow, H., Carlson, C., Bates, N., Knap, A., Michaels, A., 1995. Dissolved organic carbon as a component of the biological pump in the North Atlantic Ocean. Philosophical Transactions of the Royal Society London B 348, 161-167.

Emerson, W., Quay, P., Stump, C., Wilbur, D., Schudlich, R., 1995. Chemical tracers of productivity and respiration in the subtropical Pacific Ocean. Journal of Geophysical Research 100, 15873-15887.

Fry, B., Hopkinson, C., Nolin, A., Norrman, B., Zweifel, U., 1996. Long term decomposition of DOC from an experimental diatom bloom. Limnology and Oceanography 41, 1344-1347.

Garber, J., 1984. Laboratory study of nitrogen and phosphorus remineralization during the decomposition of coastal plankton and seston. Estuarine and Coastal Shelf Science $18,685-702$.

Garside, C., 1982. A chemiluminescence technique for the determination of nanomolar concentrations of nitrate and nitrite in seawater. Marine Chemistry 11, 159-167.

Hansell, D., Carlson, C., 1998. Deep ocean gradients in dissolved organic carbon concentrations. Nature 395, 263-266.

Hedges, J.I., 1992. Global biogeochemical cycles: progress and problems. Marine Chemistry 29, 67-93.

Hedges, J., Kiel, R., Benner, R., 1997. What happens to terrestrial organic matter in the ocean. Organic Geochemistry $27,195-212$.

Hopkinson, C.S., Fry, B., Nolin, A., 1997. Stoichiometry of dissolved organic matter dynamics on the continental shelf of the Northeastern USA. Continental Shelf Research 17, 473-489.

Jackson, G., Williams, P., 1985. Importance of dissolved organic nitrogen and phosphorus to biological nutrient cycling. Deep-Sea Research 32, 223-235.

Karl, D., Christian, J., Dore, J., Hebel, D., Letelier, R., Tupas, L., Winn, C., 1996. Seasonal and interannual variability in primary production and particle flux at Station ALOHA. Deep-Sea Research II 43, 539-568.

Karl, D., Björkman, K., Dore, J., Fujieki, L., Hebel, D., Houlihan, T., Letelier, R., Tupas, L., 2001. Ecological nitrogen-to-phosphorus stoichiometry at Station ALOHA. Deep-Sea Research II 48 (8-9), 1529-1566.

Kiel, R., Mayer, L., Quay, P., Richey, J., Hedges, J., 1997. Loss of organic matter from riverine particles in deltas. Geochimica et Cosmochimica Acta 61, 1507-1511.

Knauer, G., Martin, J., Bruland, K., 1979a. Fluxes of particulate carbon, nitrogen and phosphorus in the upper water column of the northeast Pacific. Deep-Sea Research A 26, 97-108.

Knauer, G., Martin, J., Bruland, K., 1979b. Fluxes of particulate carbon, $\mathrm{k}$ nitrogen and phosphorus in the upper water column of the northeast Pacific. Deep-Sea Research 26, 97-108. 
Ledwell, J., Watson, A., Law, C., 1993. Evidence for slow mixing across the pycnocline from an open-ocean tracerrelease experiment. Nature 364, 701-703.

Martin, J., Knauer, G., Bruland, K., 1979. Fluxes of particulate carbon, nitrogen and phosphorus in the upper water column of the northeast Pacific. Deep-Sea Research 26, 97-108.

Martin, J., Knauer, G., Karl, D., Broenkow, W., 1987. VERTEX: carbon cycling in the northeast pacific. DeepSea Research 34, 267-285.

Mitra, S., Bianchi, T., Guo, L., Santschi, P., 2000. Terrestrially derived dissolved organic matter in the Chesapeake Bay and the Middle Atlantic Bight. Geochimica et Cosmochimica Acta 64, 3547-3557.

Mopper, K., Zhou, X., Kieber, R., Kieber, D., Sikorski, R., Jones, R., 1991. Photochemical degradation of dissolved organic carbon and its impact on the oceanic carbon cycle. Nature 353, 60-62.

Moran, M., Sheldon, W., Sheldon, J., 1999. Biodegradation of riverine dissolved organic carbon in five estuaries of the Southeastern United States. Estuaries 22, 55-64.

Moran, M., Sheldon, W., Zepp, R., 2000. Carbon loss and optical property changes during long-term photochemical and biological degradation of estuarine dissolved organic matter. Limnoligy and Oceanography 45, 1254-1264.

Münster, 1993. Concentrations and fluxes of organic carbon substrates in the aquatic environment. Antonie van Leeuwenhoek 63, 243-274.

Norrman, B., Zweiffel, U., Hopkinson, C., Fry, B., 1995. Production and utilization of dissolved organic carbon during an experimental diatom bloom. Limnology and Oceanography 40, 898-907.

Ogura, N., 1972. Rate and extent of decomposition of dissolved organic matter in surface seawater. Marine Biology 13, 89-93.

Peltzer, E.T., Brewer, P.G., 1993. Some practical aspects of measuring DOC-sampling artifacts and analytical problems with marine samples. Marine Chemistry 41, 243-252.

Peltzer, E.T., Hayward, N.A., 1996. Spatial and temporal variability of total organic carbon along 140 degree $\mathrm{W}$ in the Equatorial Pacific Ocean in 1992. Deep-Sea Research 43, 1155-1180.

Peltzer, E., Fry, B., Doering, P., McKenna, J., Norrman, B., Zweifel, U., 1996. A comparison of methods for the measurement of dissolved organic carbon in natural waters. Marine Chemistry 54, 85-96.

Pietrafesa, L., Morrison, J., McCan, M., Churchill, J., Bohm, E., Houghton, R., 1994. Water mass linkages between the Middle and South Atlantic Bights. Deep-Sea Research 41, 365-389.
Press, W.H., Flannery, B., Teukolsky, S., Verterling, W., 1986. Numerical Recipes. Cambridge University Press, Cambridge, UK, 818pp.

Raymond, P., Bauer, J., 2000. Bacterial consumption of DOC during transport through a temperate estuary. Aquatic Microbial Ecology 22, 1-12.

Raymond, P., Bauer, J., 2001. Riverine export of aged terrestrial organic matter to the North Atlantic Ocean. Nature 409, 497-500.

Romankevich, E., 1984. Geochemistry of Organic Matter in the Ocean. Springer, New York, 173pp.

Schlesinger, W.H., 1997. Biogeochemistry: an Analysis of Global Change. Academic Press, New York. 588pp.

Sharp, J., Benner, R., Bennett, L., Carlson, C., Dow, R., Fitzwater, S., 1993. Reevaluation of high temperature combustion and chemical oxidation measurement of dissolved organic carbon in seawater. Limnology and Oceanography $38,1774-1782$.

Skopintsev, B., 1976. Oxygen consumption in the deep waters of the ocean. Oceanology 15, 556-561.

Søndergaard, M., Middelboe, M., 1995. A cross-system analysis of labile dissolved organic carbon. Marine Ecology Progress Series 118, 283-294.

Uhlenhopp, A.G., Hobbie, J.E., Vallino, J.J., 1995. Effects of land use on the degradability of dissolved organic matter in three watersheds of the Plum Island Sound Estuary. Biological Bulletin 189, 256-257.

Vlahos, P., Vetrano, T., Hopkins, T., Chen, R., 1998. Fluxes of dissolved organic carbon off the Middle Atlantic Bight. EOS 79, 183.

Vlahos, P., Chen, R.F., Repeta, D.J., 2002. Dissolved organic carbon in the Middle Atlantic Bight. Deep-Sea Research II 49 (20), 4369-4385.

Walsh, T., 1989. Total dissolved nitrogen in seawater: a new high-temperature combustion method and a comparison with photo-oxidation. Marine Chemistry 26, 151-183159.

Williams, P.J.leB., 1995. Evidence for the seasonal accumulation of carbon-rich dissolved organic material, its scale in comparison with changes in particulate material and the consequential effect on net $\mathrm{C} / \mathrm{N}$ assimilation ratios. Marine Chemistry 51, 17-29.

Williams, P., Druffel, E., 1987. Radiocarbon in dissolved organic carbon in the central north Pacific Ocean. Nature 330, 246-248.

Williams, P., Carlucci, A., Olson, R., 1980. A deep profile of some biologically important properties in the central North Pacific gyre. Oceanologica Acta 3, 471-476. 